\title{
POST-NEOLITHIC OCCUPATION IN TUNEL WIELKI CAVE (SOUTHERN POLAND)
}

\author{
Malgorzata Kot ${ }^{1}$, Michal Wojenka ${ }^{2}$, Grzegorz CzajkA ${ }^{1}$, Bartosz Kontny ${ }^{1}$, \\ NATALIA GRYCZEWSKA ${ }^{1}$
}

A u thors' a ddresse s: 1 - Faculty of Archaeology, University of Warsaw, Krakowskie Przedmieście 26/28, 00-927 Warszawa, Poland, e-mail: m.kot@uw.edu.pl (corresponding author), Małgorzata Kot ORCID: 0000-0001-5277-0283, Bartosz Kontny ORCID: 0000-0003-3627-046X, Natalia Gryczewska ORCID: 0000-0003-2299-8943; 2 - Institute of Archaeology, Jagiellonian University, Gołębia 11, 31-007 Kraków, Poland, ORCID: 0000-0002-6205-5627

A b s t r a c t. Post-Neolithic cave occupation in Poland remains insufficiently recognised. The purpose of this paper is to present the results of the analysis of pottery and metal objects discovered in Tunel Wielki Cave (Ojców area, SE Poland). The artefacts were collected during three fieldwork campaigns in 1967-68 and 2018. The results show that the cave was occupied at least several times. The most ephemeral settlement traces can be dated to the Early Bronze Age and these may be related to the Trzciniec culture. The site was more intensively used in the Late Bronze Age and Early Iron Age by communities representing the Lusatian culture. Roman Period artefacts are very scarce. Traces of most intensive use of the cave come from the Middle Ages. One can determine artefacts conditionally dated from the $11^{\text {th }}$ to the $12^{\text {th }}$ century, as well as younger objects, dated to the $13^{\text {th }}$ - early $14^{\text {th }} \mathrm{c}$. Single pieces of pottery can be attributed to the Modern period. The obtained results point to multiple short-term visits. The cave fill does not bear traces of permanent occupation during the Post-Neolithic period.

K e y w o r d s: Cave archaeology, Prehistoric times, Middle Ages, white Cracow-area pottery, Cracow Upland

\section{INTRODUCTION}

Research into cave sites is focused primarily on Palaeolithic occupation. Due to the good state of preservation of organic matter, cave sediments provide grounds for multiproxy paleoenvironmental analyses. In the case of Sąspów Valley, which is located in the southern part of the Cracow Upland and which together with Prądnik Valley creates the core of what is called the Ojców Jura, a significant number of cave sites have been studied so far (Fig. 1). Interestingly, the caves from Sąspów Valley produced not only Palaeolithic assemblages, but they also yielded abundant traces of Neolithic settlement. It is supposed that the reason for their popularity in the Neolithic was the nearby flint mines 


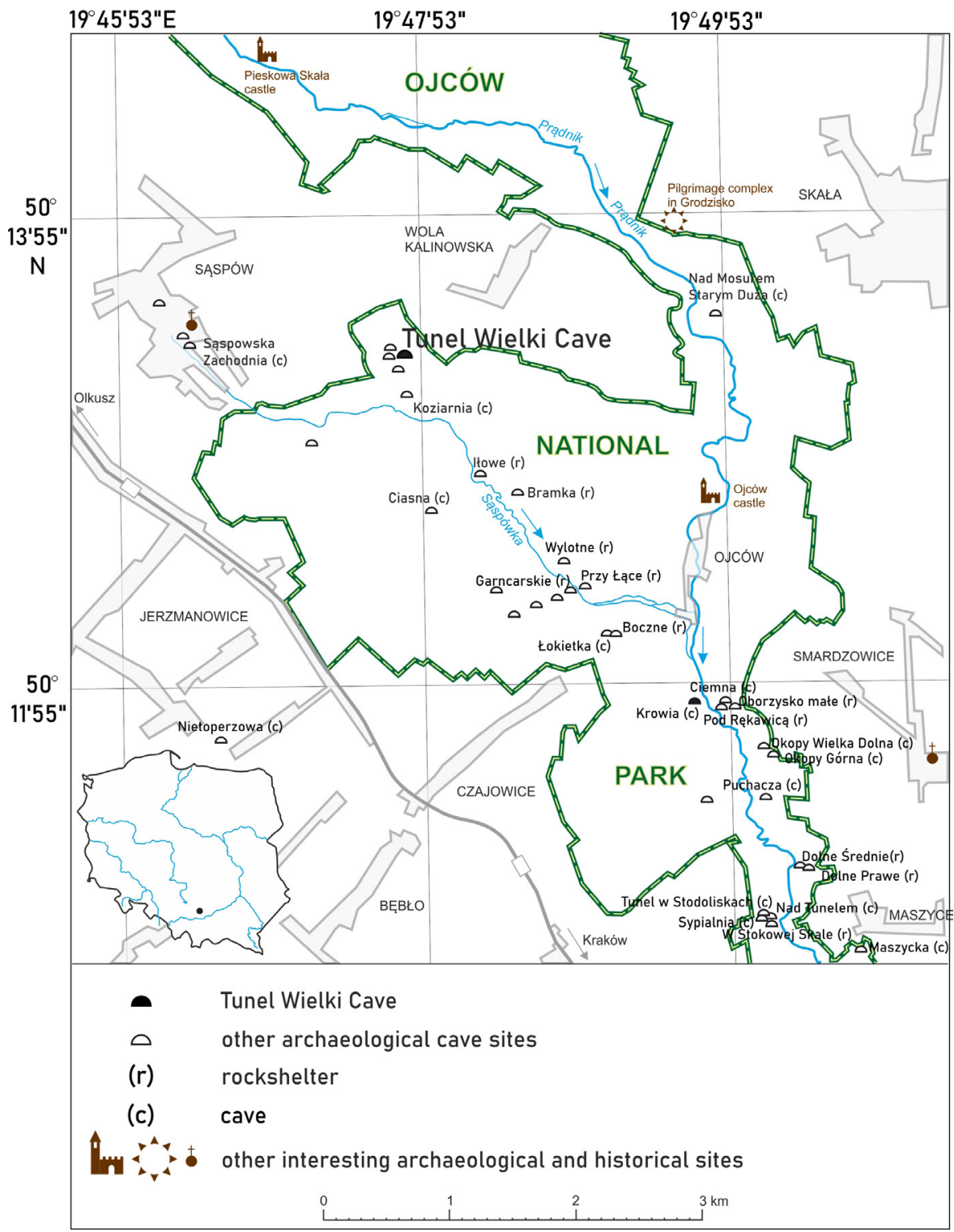

Fig. 1. Location of Tunel Wielki Cave and other archaeological caves in Sąspów and Prądnik Valleys (drawing M. Krajcarz and M. Kot)

located on the edge of the valley, which attracted people especially during the LengyelPolgár and Baden cultures (LeCH 1971, 1980a,b, 1981, 2001; RoOK 1980; ZaSTAWNY 2006, 2015). Almost all the cave sites in Sąspów Valley bear traces of either ephemeral or even more intensive Neolithic occupation (CHMIELEWSKI et al. 1988). Nevertheless, the post-Neolithic cave settlement is still rarely the focus of scientific interest, and as the issue has rarely been addressed by fieldwork and other research projects (WOJENKA 2012a,b, 2016; WoJENKA et al. 2016, 2017), the period remains poorly recognised. 
The purpose of this paper is to improve the state of research on post-Neolithic cave occupation by analysing pottery and metal assemblages from Tunel Wielki Cave, collected during three fieldwork campaigns in 1967-1968 and 2018. The paper aims at determining the distinct occupation phases of the cave and comparing them to other sites in the region. It is worth noting that the outcomes of the current examination supplement and broaden the previous approaches to the site's archaeological potential (ChMieleWski 1988; WojenKa et al. 2017; Wojenka et al. in press).

\section{TUNEL WIELKI CAVE}

Tunel Wielki Cave (Sąspów, Cracow distr.) is located in the southern part of the karstic region called Polish Jura, approximately $20 \mathrm{~km}$ north of Cracow (Fig. 1). The site is situated on the eastern slope of the Koziarnia Gorge in Sąspów Valley within the so-called Sadlane rocks, where several other cavities are located. Tunel Wielki is the largest and the highest located among them (440 $\mathrm{m}$ a.s.l). The site is a tunnellike structure with two openings and a total length of approx. 22-24 m. It consists of two chambers connected by a narrow, $8 \mathrm{~m}$ long corridor. The north chamber is wide with a large cave-mouth $(6 \times 1.5 \mathrm{~m})$, while the south one is elongated $(10 \times$ $4-5 \mathrm{~m})$, with a higher ceiling and a small opening $(1 \times 2 \mathrm{~m})$ additionally sheltered by boulders. The cave is dry and draughty, with relatively even surfaces. The north cave mouth is preceded by a large, flat terrace located approximately $50 \mathrm{~m}$ above the bottom of the valley, whereas the south entrance overlooks a steep slope leading down to the bottom of a gorge. Today, the north chamber is more illuminated and easier to access.

Tunel Wielki was first excavated in 1967-1968 by Waldemar Chmielewski, within the framework of an archaeological project concentrated on prehistoric settlement in Sąspów Valley (ChMielewski 1988; ChMielewski et al. 1969; ChMielewsKi, KozlowsKi 1968). At the time, four trenches were opened in both cave chambers (Fig. 2B): two adjacent ones in the entrance to the northern chamber and the other two in the southern chamber. In the latter, only thin Holocene and Late Pleistocene layers were found. One of the more notable findings there was a post-medieval inhumation burial of a child, discovered within the southern part of the cave (WOJENKA et al. in press). The southern chamber was revisited in 2016 by M. Wojenka and J. Wilczyński, who also found multiple human remains. Some of them were radiocarbon dated to the Neolithic (WoJENKa et al. 2017).

Noteworthy is the stratigraphic sequence found in the northern chamber. Chmielewski's excavations brought to light a $4.5 \mathrm{~m}$ deep sequence with 15 identified geological strata (MADEYSKa 1988; KRAJCARZ et al. 2016). Several layers of loams were covered with a $1 \mathrm{~m}$ thick loess stratum dated to MIS 2 and $1 \mathrm{~m}$ thick Holocene humus (MADEYSKa 1988). The first fieldworks revealed the presence of a single Middle Pleistocene rodent species Pliomys lenki (NADACHOWSKI 1988), which started a discussion on the presence of Middle Pleistocene layers in the site. 


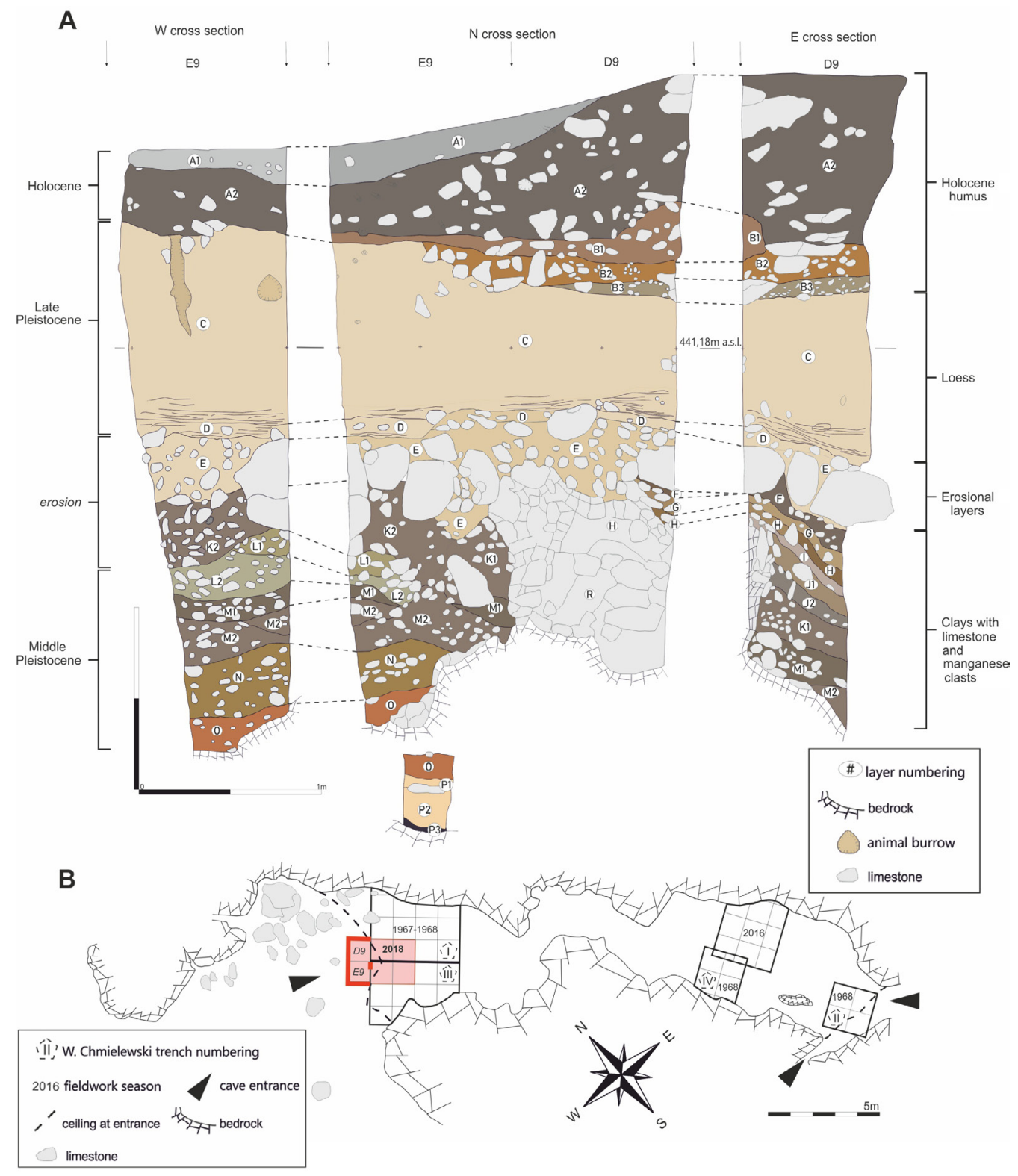

Fig. 2. Stratigraphy of Tunel Wielki Cave. A - Cross-section of the 2018 trench adjacent to the $1967 / 68$ trench by W. Chmielewski, located in the northern chamber; B - Plan of Tunel Wielki Cave with locations of all archaeological trenches (drawing M. Kot; cave outline based on archive field documentation from 1967-1968).

New fieldworks were launched in 2018 aimed at testing the previous statements. Old trenches in the north chamber were reopened and extended in order to collect geological, chronostratigraphic and paleoenvironmental data.

The stratigraphic sequence in the north chamber (Fig. 2) starts with an approx. $1 \mathrm{~m}$ thick black humus layer with limestone rubble that accumulated during the Holocene 
(layers A2, B1, B2 and B3). Below the humus strata, an approx. $1 \mathrm{~m}$ thick loess layer (layer C) was found. Beneath it, there was another loess layer, around $0.6 \mathrm{~m}$ thick, but with limestone (layer D). The sequence continues with erosional layers with mixed silty loam and large amount of limestone rubble (layers E, K1, L1 and L2), covering a series of clay layers over $1.5 \mathrm{~m}$ thick with clasts of manganese and limestone rubble (layers F, G, H, I, J1, J2, M1, M2, N, O and R). The sequence ends with several thin layers of silty and sandy loams without limestone (layer P1-P3).

The characteristic sinking of the layers at the bottom may indicate that the cave is connected with another cavity called Rock Shelter under Tunel Wielki, which was also excavated in 1968 (CHMIELEWSKI 1988). It cannot be ruled out, however, that both caves form part of a larger karstic system including yet another cavity, called Rock Shelter above Niedostępna Cave (Dziurawiec Stromy), which is situated below Tunel Wielki.

\section{MATERIALS}

This paper aims at analysing post-Neolithic pottery and metal artefacts found during the fieldworks conducted in 1967-1968 by Waldemar Chmielewski (1988), as well as those conducted in 2018 by the authors. According to Chmielewski's field inventory of finds, during the 1967-1968 campaign a single bead, a single bronze artefact (Fig. 3: 6) and a total of 438 pottery pieces were recovered from four archaeological trenches situated in three different locations within the cave (trenches I-IV). The archaeological materials of Holocene date have never been analysed or published before. They were catalogued and revaluated in 2017. At present, the bead is missing and this makes it impossible to determine its chronology and the raw material used. The single metal object (Fig. 3: 6) as well as around 400 pottery pieces are available for further analyses. It is worth noting that it was the north chamber (trenches I and III) where a vast majority of them were found $(87.5 \%, \mathrm{n}=383)$.

The fieldworks in 2018 covered 2 square metres of previously unexcavated surface, as well as 4 square metres of the old trenches. In total, 234 pottery pieces were found during the exploration of the in situ Holocene layers, 0.5-1 m thick (Fig. 2). The sediment was additionally wet-sieved on $1 \mathrm{~mm}$ mesh. As a consequence, four metal artefacts (Fig. 3: 5, 7) and over 500 small pottery pieces were collected. Additionally, the backfill of the old trenches was excavated using archaeological methods and wet sieving ( $3 \mathrm{~mm}$ mesh), producing over 1,000 potsherds and 13 metal objects, including a bronze arrowhead (Fig. 4: 4).

To sum up, the 1968-1969 and 2018 excavations yielded over 2,200 pottery pieces and 18 metal artefacts. With respect to the pottery finds it needs to be emphasised, however, that the state of their preservation varies. The materials obtained by wet-sieving $(n>1500)$ are highly fragmented, and their chronological identification is possible only to a limited extent, although some pieces of medieval pottery are an exception in this respect. For this reason, the basis for the following analyses were mainly the objects 


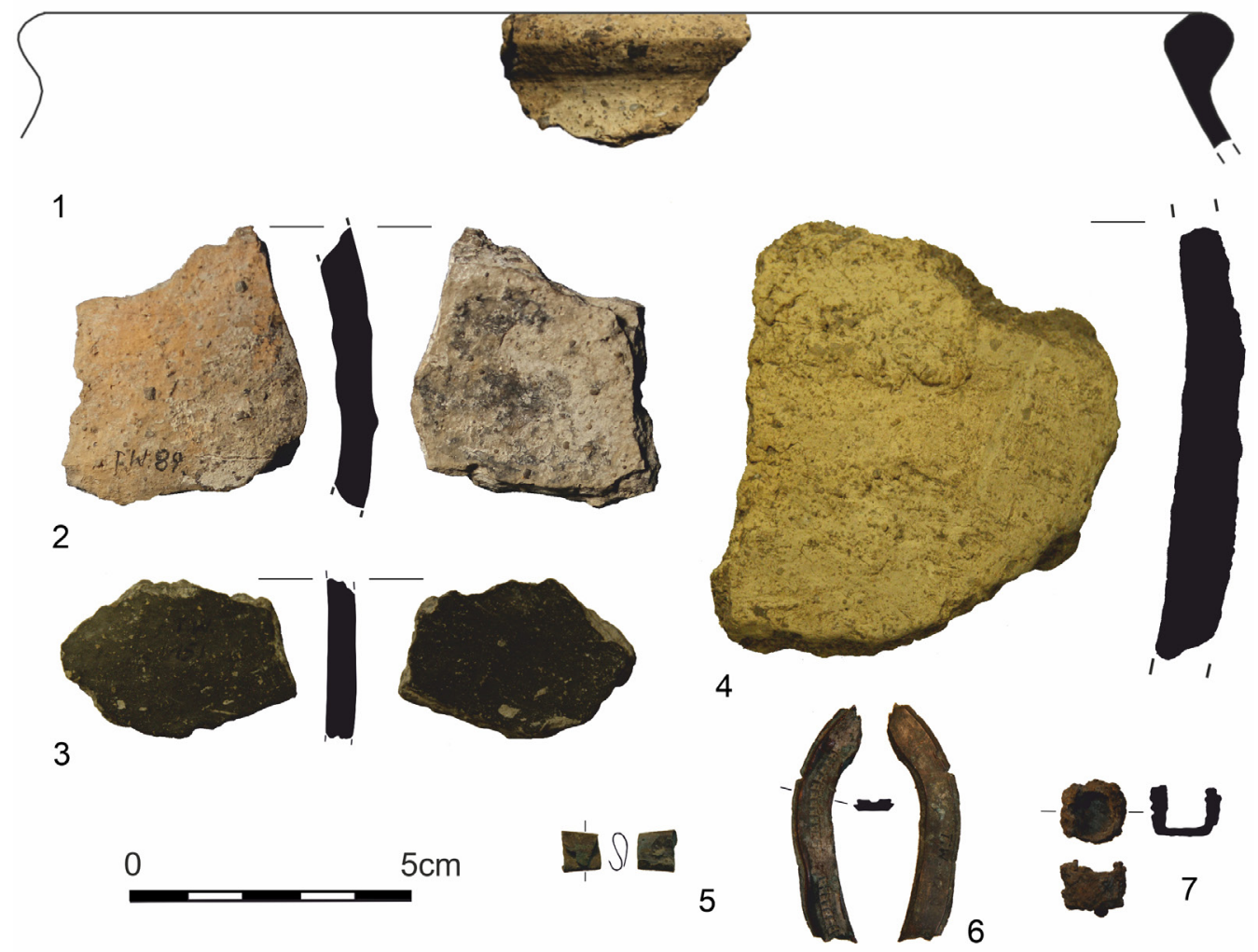

Fig. 3. Pottery and metal artefacts found in Tunel Wielki Cave. 1-3-pottery pieces dated to Roman Period; 4 - pottery dated to the Early Bronze Age (Trzciniec culture); 5 - S-shaped bronze artefact; 6 - bronze or brass artefact; 7 - iron bucket-shaped pendant (photos and drawings: M. Kot and M. Wojenka)

discovered in situ during the 1967-1968 and 2018 excavations and within the backfill of the old trenches $(n=659)$. Some of these artefacts belonged to the Neolithic or were undeterminable. The Neolithic material, due to the presence of human remains in the strata, will be addressed in a separate paper.

Among the metal artefacts, there are 12 unidentifiable pieces of iron ranging from $5 \mathrm{~mm}$ up to $35 \mathrm{~mm}$ in length, two pieces of small flat iron plates $10-15 \mathrm{~mm}$ in diameter, and four more characteristic artefacts. The latter group includes an S-shape bronze plate of undeterminable chronology (Fig. 3: 5); a fragmentarily preserved, curved and elongated flat bronze or brass object of undetermined function and chronology, adorned with a line of knurled dots (Fig. 3: 6); a bronze arrowhead (Fig. 4: 4); and an iron artefact which might be a bucket-shaped pendant possibly of type III/2 after P. Kaczanowski (1987: 68), from the Younger or Late Roman Period (Fig. 3: 7). The last two artefacts are presented in detail in the latter part of the text. It is worth mentioning that both the S-shaped bronze plate and the iron artefact were found during the 2018 season in square E9. 

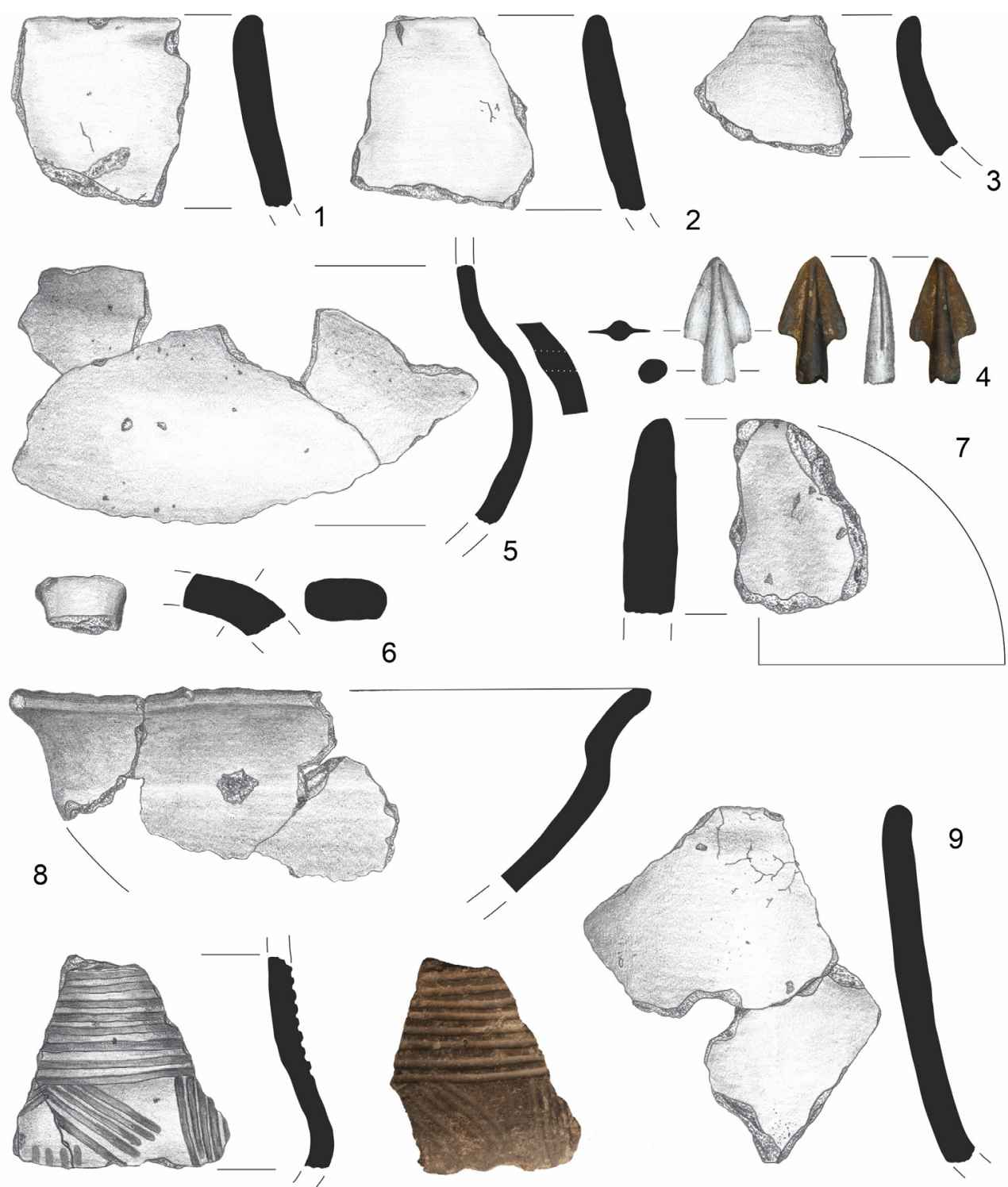

10
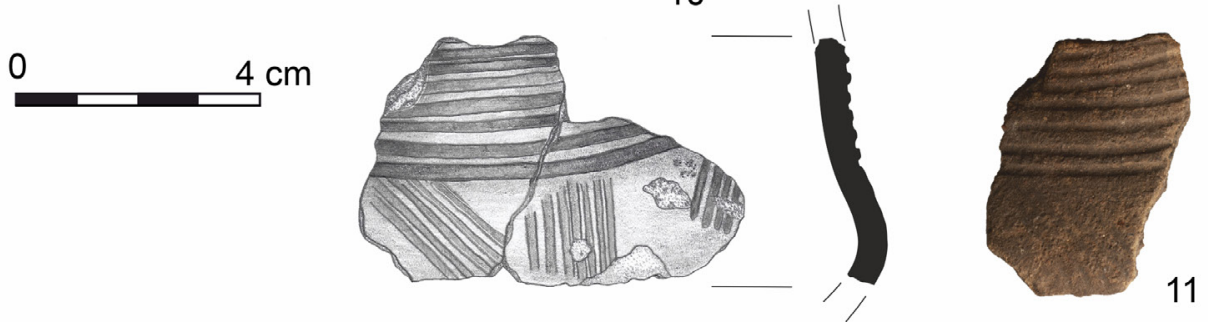

Fig. 4. Pottery and a bronze arrowhead linked with the Lusatian culture found in Tunel Wielki Cave (photos and drawings G. Czajka) 


\section{BRONZE AGE AND EARLY IRON AGE}

Two distinct occupation phases can be determined within the assemblage. The first one is represented only by a single fragment of Trzciniec culture pottery from the Early Bronze Age. The second phase is linked with the Lusatian culture from the Late Bronze Age up to $\mathrm{HaC}$.

A single body sherd found in Tunel Wielki Cave in 2018 can be attributed to the Early Bronze Age (Fig. 3: 4) due to its roughened and cracked surface characteristic of the Trzciniec culture. The sherd is too small to conclude on the original form of the vessel.

Pieces of Trzciniec culture pottery were also found in the Rock Shelter under Tunel Wielki. These are two unornamented body sherds with thickened, faceted rims (Fig. 5: 8), a feature characteristic primarily of assemblages of the A1 and A2 types (GóRSKI 2007: 54, 60, 76). Trzciniec culture artefacts were also found in Ciemna Cave (JęDRYsik 2016: 121), Wierzchowska Górna Cave (JĘDRYsIK 2016: 159, 160), Górna Cave in Ogrójec (JęDRYsIK 2016: 106, 107), Łokietka Cave (JęDRYsiK 2016: 127), and Koziarnia Cave (ChMielewski et al. 1967: 53; Mościbrodzka 1971: 65).

The ceramic assemblage from Tunel Wielki Cave includes 30 pieces of pottery unambiguously assigned to the Lusatian culture, and another 137 sherds very likely representing this culture. The artefacts attributed to the Lusatian culture include a rim fragment from an unornamented plate (Fig. 4: 7), two rim sherds from one or two vases (Fig. 4: 1,2) with straight rims and conical flaring necks. Vessels of such shape can be found in assemblages of the Silesian group and are dated to the Late Bronze Age (Bronze Age Period V) with examples known from Wrocław-Widawa, site 17 (LASAK 2014: 112, 152, 153, fig. 11.2) but they are also known from the Górnośląsko-Małopolska (Upper Silesia and Lesser Poland) group of the Lusatian culture (e.g. Ciasna Cave; Czajka 2019: fig. IV, V:1). However, the size of the sherds from Tunel Wielki does not allow their chronology and typology to be precisely determined. Another rim sherd (Fig. 4:3) probably belonged to a vase having a relatively short neck. The technology of its manufacture suggests a chronological attribution similar to the fragments described above. One rim belonged to a vase with a conical neck (Fig. 4: 9). The neck has a hole drilled through it, possibly a trace of repair. As its manufacturing technology is similar to the previously described pieces, it can be dated to the Late Bronze or Early Iron Age (Period V-HaC). The other interesting piece comes from a thin-walled vessel with a smoothed surface, straight rim, and conical neck (Fig. 4: 5). Additionally, it has traces of a handle attached using a square pin.

Another group of Lusatian culture pottery recorded in this site is comprised of bowls. Two or three profiled bowls with smoothed dark surfaces were found in Tunel Wielki Cave. The fabric of these vessels contains a mid- and coarse-grained mineral admixture. The bowls were made carelessly, without maintaining symmetry (Fig. 4: 8). A fragment of a ceramic handle (Fig. 4: 6) probably originally belonged to such a bowl. The handled bowls can be attributed to type $G$ in Durczewski's typology $(1946: 56,59,60)$. This is one of the most popular bowl types in the 
Górnośląsko-Małopolska group of the Lusatian culture, and it can be dated to the Late Bronze Age and Early Iron Age (Period V-HaC) (Durczewski 1946: 60, 61; SUDER 2000: 187).

The ornamented pottery is only represented by four neck and body sherds (possible to partially conjoin) probably originating from one miniature vase decorated with oblique grooves on the body and a series of horizontal engraved lines on the neck (Fig.4: 10, 11). This form is analogous to the vases from Ciasna Cave (CzAJKa 2019: fig. V: 3).

The bronze arrowhead (Fig. 4: 4) is also noteworthy. It has a triangular blade without barbs, and a round socket. It represents subtype Aa of the I ${ }^{\text {st }}$ type in Fogel's typology (Fogel 1979: 112, 113). The artefact has a bent tip, which suggests that it hit a hard surface, presumably the cave wall. Similar arrowheads are known mainly from Bronze Age Periods III and IV, but they were used up to the Early Iron Age (FogEL 1979: 113). In the south chamber, two similar bronze arrowheads were found during the 2016 fieldworks (WoJENKA et al. 2017: 164).

Interestingly, these arrowheads also have traces of impact into a hard surface, such as a cave wall. Since they are provided with two barbs, they should be assigned to the II ${ }^{\text {nd }}$ type subtype A in Fogel's typology. Such arrowheads can be dated from the Bronze Age Period III up to the Hallstatt Period, but they are most widespread in the Late Bronze Age (Fogel 1979: 113, 114). Due to the absence of artefacts datable to the early phases of the Lusatian culture, their chronology has to be considered in the context of the remaining assemblages from the cave, thus from the Bronze Age Period $\mathrm{V}$ up to $\mathrm{HaC}$.

\section{TRACES OF ROMAN PERIOD OCCUPATION}

Although the aforementioned period is poorly represented in the archaeological record from the site, one can identify over 20 potsherds attributed to the Przeworsk culture. The attribution is based mostly on the form of a few faceted rims (TW A36/2018 - Fig. 3: 1, TWB 437/2018, TWB 438/2018, TW A120/2018), some of which are unfortunately too small to credibly reconstruct the diameters of the vessels. One can assume that they represent fragments of wheel-thrown pots, including pots with a neck (RODZIŃSKA-NOWAK 2006: pl. V:2, XLIV:4, LXII:2; URBANIAK 2008: 68-70: pl. LXVI:5). Such rims have parallels among the finds from the settlements at Jakuszowice, distr. Kazimierza Wielka (rims of group II.17.b after RoDziŃsKANoWAK 2006: pl. LXXII:17.1), Złota, distr. Sandomierz (type WS14 after URBANIAK 2008: list 9), and Igołomia, distr. Kraków (profile 12 or 13 - DobrZaŃsKA 1990: fig. 8: 12, 13, see fig. 12:34, LVII:2, LXCIV:14). One fragment of a rounded belly (TW7/1967) suggests a different form, namely a vase or bowl (DoBRZAŃsKA 1990: fig. 14:51-53, 60; RodzIŃSKa-NowaK 2006: pl. V:4, XIII:5, XIV:5-6, XVI:1, XXII:7, XXV:6-7, 10, XL:5, XLV:5, LXI:2), and another fragment (TW91/1967) - hand-made - comes from a gently profiled pot with a wide mouth and the rim straight or slightly bent inwards (groups III and IV/2 after LIANA 1970: pl. II:12, 14, 
18, 21; type 56 after DobrZaŃsKa 1990: fig. 14: 56, pl. XXI:7). Additionally, there are less characteristic belly fragments (Fig. 3:2). The potsherds are mostly pinkishbrown in colour with medium- and fine-grained mineral admixture of crushed stone, well visible on coarse and undecorated surfaces. On some sherds, one can notice parallel lines which are technological traces indicative of the vessel being made on a potter's wheel (TW A18/2018, TW A47/2018). One thin-walled body fragment is black in colour and smooth (Fig. 3: 3 - TW151/1967), which suggests its possible early chronological position. Together with another black-surfaced piece they may be dated even as far back as the late stage of the Early Roman period, although subphase C1a (see Liana 1970: 439, 440; DobrZaŃSKa 1990: 55, fig. 13; RoDZiŃSKA-NowaK 2006: 139-141) seems more likely taking into account the other materials. These materials - such as the Przeworsk-culture wheel-made vessels - should be dated in their bulk to phases C2-D, although the potter's wheel appeared there as early as subphase C1a (RoDzIŃSKA-NowAK 2010: 82, 83) and similar forms of thickened rims may be dated even to subphase C1b (DobrzańsKa 1990: fig. 19). The same refers to the possible bucket-shaped pendant which was found in square E9, a part of the trench relatively abundant in Roman-period artifacts. Such forms appeared generally during phases C2-C3 (KACZANOWsKi 1987: 70).

\section{TRACES OF MEDIEVAL OCCUPATION}

The excavations of 1967-1968 and 2018 provided much information on the cave's medieval occupation. Moreover, the number of artefacts obtained via these fieldworks makes this cave one of the most important sites for landscape reconstruction in the Ojców area during the Middle Ages. The assemblage in the spotlight of this chapter consists exclusively of pottery sources, but they represent at least two separate moments in the past when the cave was visited by a human or a group of people. All the finds came from the uppermost humic layers of the cave's rich stratigraphic sequence, for the most part from layer A2 (Fig. 2).

Prior to describing the above assemblage as a whole, it is vital to address the issue of medieval finds discovered in the cave's south chamber in 2016 (WoJENKA et al. 2017). These excavations yielded 51 pottery sherds and two lead objects, one of which is very similar to artefacts usually regarded as weights. The relative chronology of the ceramic sources was determined as the $13^{\text {th }}-$ mid $14^{\text {th }}$ century, while the lead objects were dated earlier, from the mid- $11^{\text {th }}$ to the early $13^{\text {th }}$ century (WoJENKA et al. 2017: $159,160,164)$. To verify if this chronological observation about human activities in this cave still holds true, let us examine the medieval ceramic assemblage retrieved during the 1967-1968 and 2018 excavations.

The finds in question are 371 pottery sherds, representing a maximum of 331 different 'ceramic units'. The number of ceramic vessels is difficult to ascertain, although in light of the preserved rim fragments there is no doubt that the assemblage contained at least 14 separate vessels. Their state of preservation is, however, poor. The analysis 


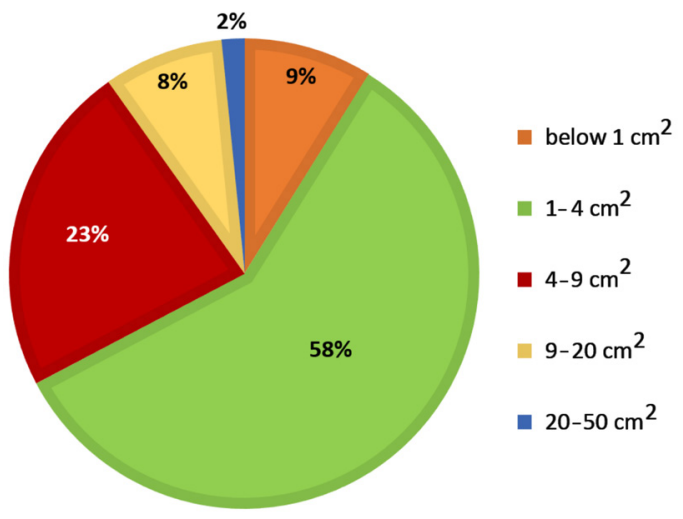

Fig. 5. The level of fragmentation of medieval pottery sherds

revealed that more than half of the sherds are small fragments $\left(1-4 \mathrm{~cm}^{2}\right.$ and less; see Fig. 5). Given the heavily fragmented nature and the erosion of much of the finds, one may consider a high rate of post-depositional processes in the topmost part of the cave filling (see BuKo 2008). At least to some extent, this may be associated with recent cuts and pits revealed by $\mathrm{W}$. Chmielewski even prior to the excavations in the 1960s (MADEYSKA 1988: 107; see also Fig. 11). When it comes to the state of pottery preservation it is important to note that the surfaces of numerous sherds are covered by a thin layer of calcium carbonate (Fig. 8: 3, 15-18, 21, 25; cf. MADEYSKA 1988: 118), indicating that they remained on the cave floor unburied over a long period of time.

When it comes to the technology of the production of vessels, it needs to be emphasised that all the ceramic artefacts were made of iron-rich clays commonly occurring in SE Poland, but the ceramic paste differed in terms of the amount of temper. Examining the pottery sources, four different types of paste were macroscopically identified (Fig. 6). Fabric I may be characterised as well-lavigated, fairly smooth and relatively soft, with a rather small amount of sandy temper, usually around $0.1-0.5 \mathrm{~mm}$, and with a noticeable admixture of calcium carbonate (crushed limestone; grains approx. $1 \mathrm{~mm}$ ). Fabric II seems to be quite similar to Fabric I, although no traces of crushed limestone

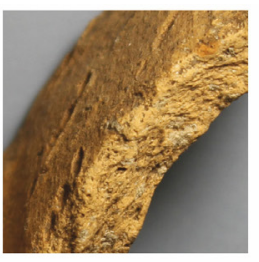

Fabric I

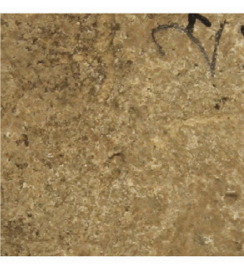

Fabric /I

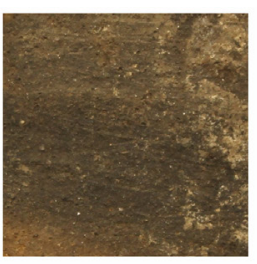

Fabric III

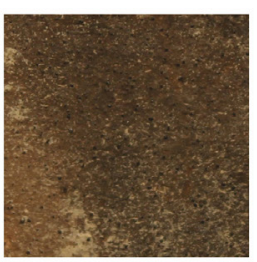

Fabric IV

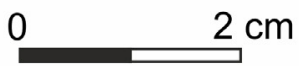

Fig. 6. Medieval pottery fabrics (photos M. Wojenka) 


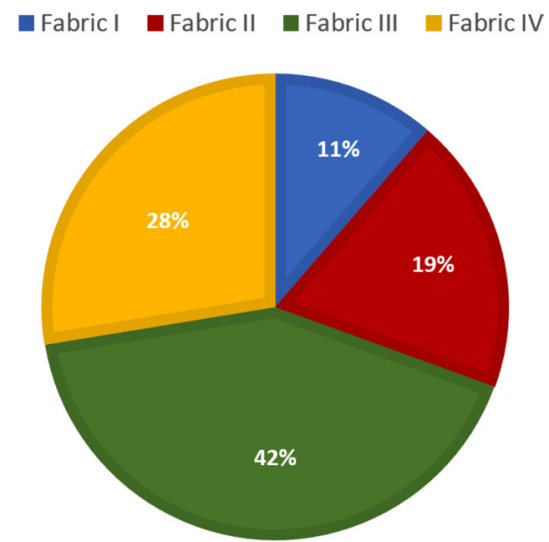

Fig. 7. Percentage of medieval pottery fabrics

were noticed. Fabric III can be described as fairly coarse gritty with a smaller amount of sandy temper, usually around $0.1-0.5 \mathrm{~mm}$. Fabric IV is hard coarse and gritty, but sand is added in much greater amounts; in some cases, small grains of gravel appear (cf. WoJENKA et al. 2017: 156-158).

The percentage frequency of particular fabrics from Tunel Wielki Cave is diverse, although fairly and hard coarse gritty tempers prevail in the assemblage, reaching $70 \%$ in total (Fig. 7).

The analysed material undoubtedly comes from vessels manufactured using the technique of kneading and wheel-throwing. This technique is confirmed by traces of jointing successive coils or strips, and by bottoms with preserved external rings, evidenced in the case of seven ceramic units (see Holubowicz 1950: 159; LePównA 1968: 84; NiEGODA 1999: 162). The use of a potter's wheel is also confirmed by a potter's mark seen on the bottom of one vessel, depicting a simple convex cross (Fig. 8: 26; see: BuKo 1990: 141).

The medieval vessels from the cave were fired in an oxidising atmosphere in a hearth or kiln. In the majority of cases they were relatively poorly fired: the orange or light orange colour of the surfaces, which may be regarded as indicating a strong firing, was recorded only in $37 \%$ of the studied assemblage. In most cases, the colour of the vessels varied from light brownish to brownish-grey, which suggests a rather short firing process (see HoŁUBOwicz 1950).

The pottery from Tunel Wielki Cave differs in terms of section colour. Most of them have monochromatic, brown, brownish or light orange sections $(66 \%)$. Bi-, threeor four-coloured sections are represented by $17 \%, 14 \%$ and $3 \%$ of the assemblage, respectively.

Due to the high degree of pottery fragmentation it is difficult to draw firm conclusions about the formal diversity of the studied assemblage, although if we consider the average set of kitchen wares used at this stage of the Middle Ages, the classification of our pottery fragments as pots seems more than likely correct (see BuKo 1990). It has to be recognised that pots are readily recognisable among pottery sherds thanks to the preserved rim fragments (Fig. 8: 1-11), representing both simple (Fig. 8: 1, 2, 8) 

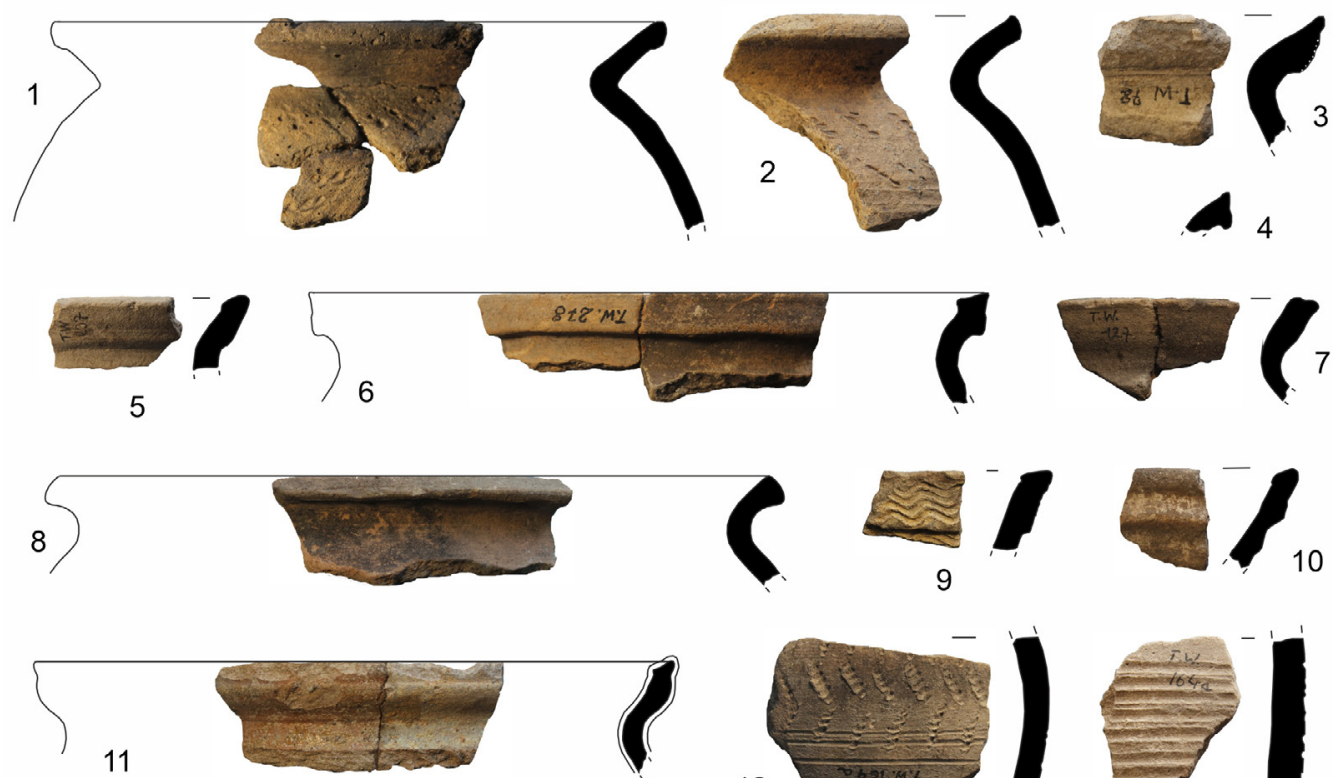

12
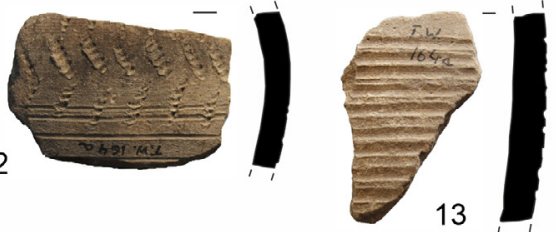

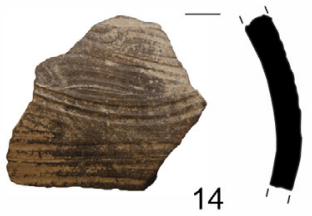

14
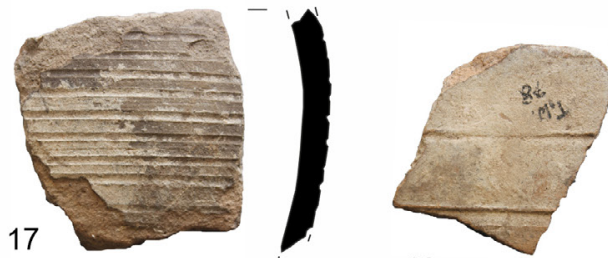

18

15
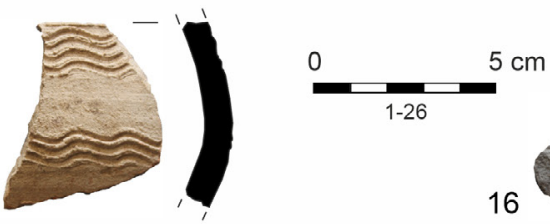

16
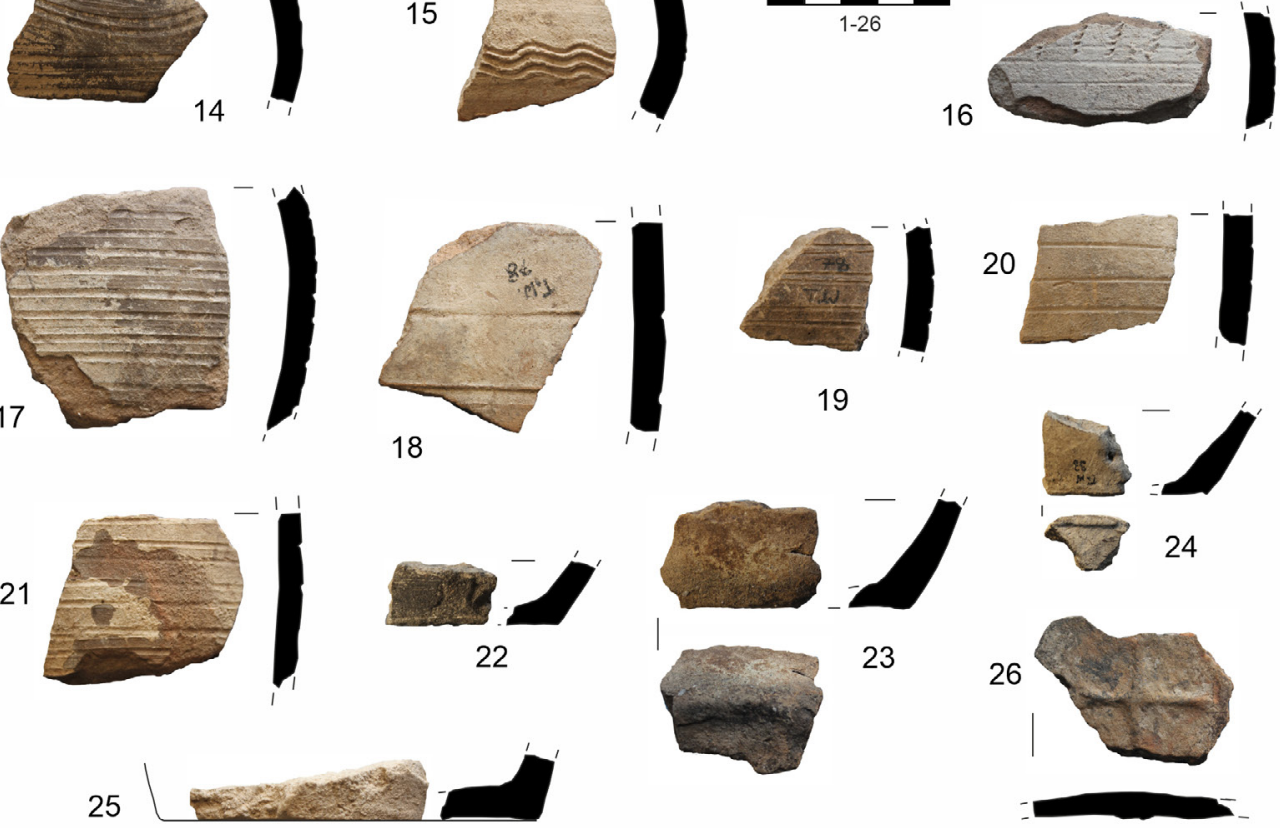
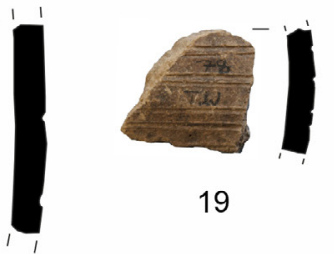

20

19
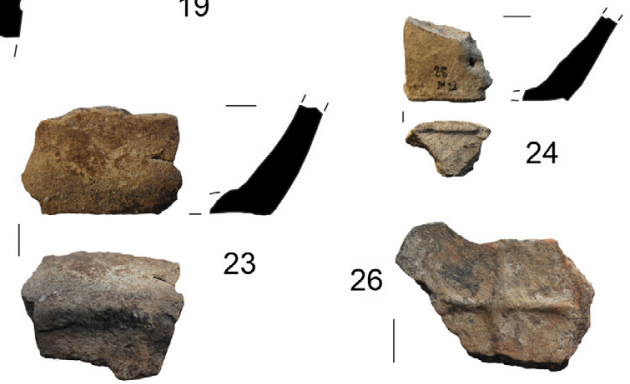

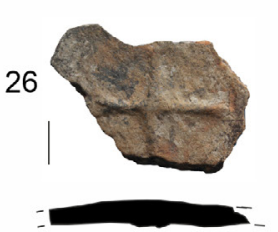

Fig. 8. Medieval pottery. Fabric I - 1-4, 15, 17; Fabric II - 5, 8, 10, 13, 18, 25; Fabric III - 6, 7, 9, 11, 12, 14, 16, 19, 20, 21, 24; Fabric IV - 5, 17, 22, 23, 26. The north chamber: 1, 2, 4-7, 9-16, 19-26; the south chamber: $3,8,17,18$ (photos and drawings M. Wojenka) 
and highly profiled forms (Fig. 8: 3, 6, 9-11). The diameters of rims vary from 140 $\mathrm{mm}$ (Fig. 8: 11) to $180 \mathrm{~mm}$ (Fig. 8: 1, 6) and even $200 \mathrm{~mm}$ (Fig. 8: 6), while the reconstructed diameter of one bottom is $100 \mathrm{~mm}$ (Fig. 8: 25). The lowermost parts of the wares are rather straight (Fig. 8: 22-25).

The medieval vessels from Tunel Wielki Cave were commonly ornamented $(37 \%$ of units), mainly with more or less regular, engraved horizontal stripes (Fig. 8: 13, 17-21) or engraved waves (Fig. 7: 15), sometimes combined with repeated incised ornamentation (Fig. 8: 1, 2, 12). One of the rim fragments discovered in the north chamber was adorned with engraved wavy lines (Fig. 8: 9), and, noticeably, it likely comes from the same pot as a rim discovered in 2016 in the south chamber of the cave (WoJENKA et al. 2017: 161, fig. 6.11).

Closing the remarks about the external appearance of the wares from Tunel Wielki it is important to note that the ceramic assemblage contains some wares glazed on the outside (6 units), both with olive-green (5) and semi-transparent glaze (1 unit; see Fig. 8: 11).

Moving on to the chronology of the medieval activity at Tunel Wielki Cave from the outset it needs to be said that in technological and formal terms the assemblage in question appears to be heterogeneous, reflecting at least two separate moments during the Middle Ages when the cave witnessed some human presence.

The earlier stage of human activity may be indicated via the raw material of Fabric I, which corresponds with the so-called "white pottery of the Cracow area", generally dated from the $8^{\text {th }}$ to the turn of the $12^{\text {th }}$ century, although it must be stressed that its frequency gradually decreased since the late $10^{\text {th }}$ century (RADWAŃSKI 1968: 24; see also KUBICAKABACIŃSKA 2001; KUKLIŃSKI 2017: 36-40). It is important to note that the evidence of "white Cracow-area pottery" from Tunel Wielki Cave is only the second example from the Cracow Upland - the first came from Korzkiew, Cracow district (NowaK et al. 2016). When it comes to the chronology of our vessels representing Fabric I, particular attention should be drawn to the rim fragments (Fig. 8: 1-4), which find close parallels among materials discovered in other sites from the region. The specimens depicted on Figures 8: 1 and 8: 2 correspond with types 7-8 of rims from Cracow by Kazimierz Radwański, which appear to have been used from the second half of the $10^{\text {th }}$ to the early $11^{\text {th }}$ century, although incidentally they might have appeared up to the $12^{\text {th }}$ century (RADWAŃSKI 1968: fig. 39). Similar rims were discovered in the inhumation cemetery dated to the mid-1 $11^{\text {th }}$ - early $12^{\text {th }}$ century from Strzemieszyce Wielkie, Dąbrowa Górnicza distr. (MARCINIAK 1960: pl. I.2; VI.15); at the open-air settlement in Przeczyce, Będzin distr., dated to the mid- $11^{\text {th }}$ and $12^{\text {th }}$ centuries (NIERYCHLEWSKA 2011: 133, 137, pl. IV.5, V.4, VIII.7); and in Dąbrowa Górnicza-Łosień, Dąbrowa Górnicza distr. (Rozmus 2014: 235, fig. 216: 5-6, 8-9; 236: fig. 217.2, 5-6), where analogous finds have to be considered in broader time frames, from the (mid) $11^{\text {th }}$ century to the turn of the $13^{\text {th }}$ (RozMus 2014: 234, 242). A similar chronology can be attributed to the rim depicted on figure 8: 4, which shows close affinities with Radwański's type 23, occurring in Cracow from the $10^{\text {th }}$ to the early $13^{\text {th }}$ century (RADWAŃSKI 1968: fig. 39). Noteworthy, similar rims occurred in Strzemieszyce Wielkie (MARCINIAK 1960: pl. VII.2) and Przeczyce as well (NIERYCHLEWSKA 2011: 134, pl. V.3). 
Considering the earlier set of ceramics from the cave, it is possible to state that at least some percentage of the wares made from Fabric II belong to this group. Single rim fragments representing Fabric II (Fig. 8: 8) closely correspond to Radwański's type $11\left(9^{\text {th }}-11^{\text {th }}\left(12^{\text {th }}\right)\right.$ c.; RADWAŃSKI 1968: fig. 39), a type which was also recorded at the aforementioned site in Strzemieszyce Wielkie (MARCINIAK 1960: pl. IV.30, V.4).

In light of the information given above, it is hard to resist the impression that the earlier group of pottery cannot be dated precisely. As has already been said, analogous materials from the same region are commonly dated between the second half of the $10^{\text {th }}$ and the $12^{\text {th }}$ centuries or even the turn of the $13^{\text {th }}$, and this seems to be a secure dating for this part of the assemblage from Tunel Wielki Cave. There is, however, an indirect indication suggesting more narrow time frames, namely a lead object discovered in the south chamber in 2016. It is dated from the mid- $11^{\text {th }}$ to the turn of the $13^{\text {th }}$ century, and it seems to relate closely with the area of the Cracow-Silesian borderlands (WoJENKA et al. 2017: 163, 164, fig. 7.12). Its occurrence in the cave, combined with the decline of the so-called "white Cracow-area pottery", encourages us to suppose that the studied set of ceramics may reflect some human activity from the $11^{\text {th }}$ to the $12^{\text {th }}$ century.

The later stage of medieval activity at the site can be dated broadly to the $13^{\text {th }}$ and the early $14^{\text {th }}$ centuries. This is indicated by the rim fragments (Fig. 8: 5, 6, 7(?), 9-11) which have a number of close parallels in Cracow (see types 54-55; RADWAŃSKI 1968: fig. 39), at the stronghold in Piekary, Cracow distr., dated from around the mid-13 $3^{\text {th }}$ century to the turn of the $14^{\text {th }}$ (LEŃCZYK 1938: pl. XVI-XVII), and at the fortified site in Grodzisko near Skała, Cracow distr., dated to the mid-13 $3^{\text {th }}$ - early $14^{\text {th }}$ century (WoJENKA et al. 2019: 97, fig. 8.6), to mention just a few examples.

\section{TRACES OF POST-MEDIEVAL OCCUPATION}

The post-medieval occupation is only represented by six small pieces of pottery. Three of them, discovered in the north chamber, are the remains of two or three faience forms. The finds are adorned with diverse blue motifs depicted on a white background (Fig. 8; see MACKIEWICZ 2012: 155-157). Three other ceramic units are represented by tiny fragments of vessels made of white clays. The poor state of preservation of

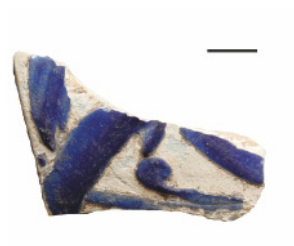

1

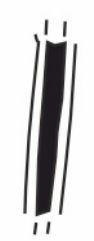

0

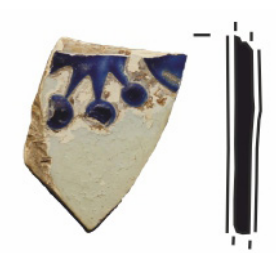

2

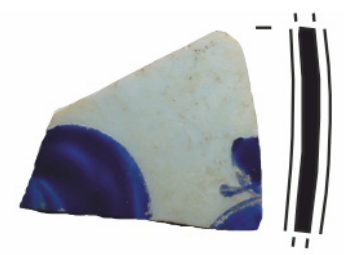

3

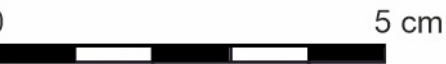

Fig. 9. Post-medieval faience (photos and drawings M. Wojenka) 
all the sherds does not allow for firm chronological conclusions, although the abovementioned faience objects undoubtedly come from later stages of the post-medieval period (possibly the $18^{\text {th }}$ c. or later; Fig. 9: 1, 2) or even from modern times (Fig. 9: $3)$. Last but not least, considering the post-medieval or modern-period objects, the bronze or brass find depicted in Figure 3: 6 should be mentioned. The function and chronology of this object must remain uncertain, though regarding its design the impression is given that it comes from recent times.

\section{PLANIGRAPHY}

The planigraphy of the described materials (Fig. 10) shows a higher concentration of artefacts in the western part of the 1967-68 trench. This is not due to the methods of exploration, because a similar diversity in concentrations of artefacts can be observed in the trench from 2018. This situation is also not due to the thickness of the Holocene layers, which were even thicker in the eastern part of the cave (Fig. 2). For this reason, one can assume the concentration may reflect human activity. In the eastern part of the main trench, called trench I, Chmielewski found numerous pits and cuts. Some of them even reached the loess stratum underneath (Fig. 11). Unfortunately, the artefacts were not collected from particular cuts separately, so it is currently impossible to determine the chronology of the identified structures. Therefore, artefacts dated to all the settlement phases were found throughout the entire thickness of the Holocene stratum, probably due to the mentioned cuts.

\section{DISCUSSION AND CONCLUSIONS}

Summing up, one can determine multiple, possibly short-term visits in the Tunel Wielki Cave. The examination of the finds described in this paper has made it possible to broaden the recent perspective on post-Neolithic occupation in this cave (WOJENKA et al. 2017). Now, the most ephemeral traces of human activity can be dated to the Early Bronze Age and are represented by a single piece of Trzciniec culture pottery. Artefacts dated to the Early Bronze Age have been found so far in several cave sites such as Ciemna Cave (JęDRYsiK 2016: 121), Wierzchowska Górna Cave (JęDRYsIK 2016: 159, 160), Górna Cave in Ogrójec (JęDRYsIK 2016: 106, 107), Łokietka Cave (JęDRYSIK 2016: 127) or Koziarnia Cave (CHMielewsKi et al. 1967: 53; MościbrodzKa 1971: 65).

The intensification of the cave use can be dated to the Late Bronze Age and Early Bronze Age and is connected with the Lusatian culture. Traces of Lusatian culture occupation have been found in 18 cave sites in the region, which might be linked with the presence of an open settlement site found recently in Ojców Castle (WOJENKA 2016). Still, the number of Lusatian artefacts in most cave sites is low (1-30 pottery pieces).

It is noteworthy that Lusatian culture artefacts were also found in Rock Shelter under Tunel Wielki and Rock Shelter above Niedostępna Cave, located right next to 

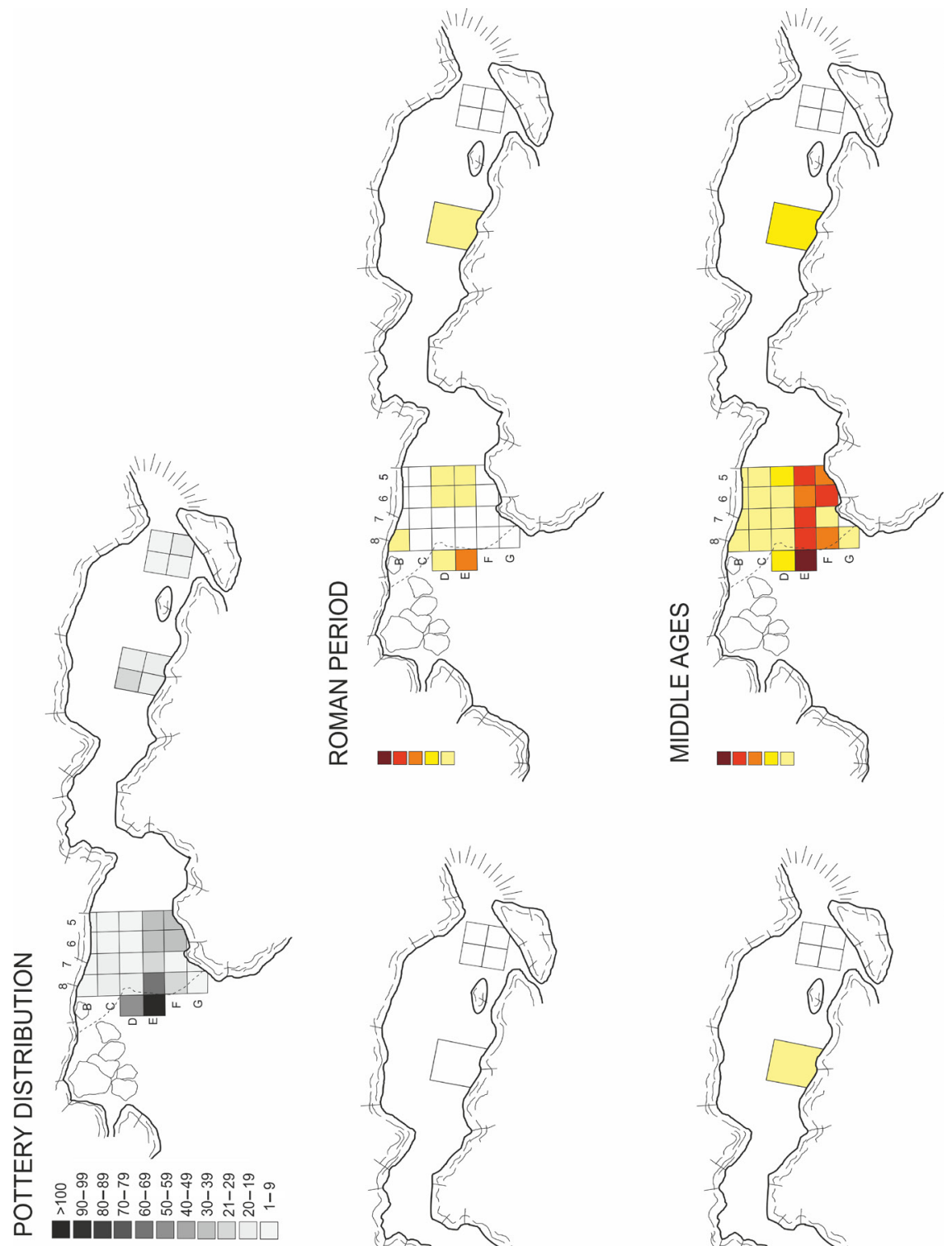

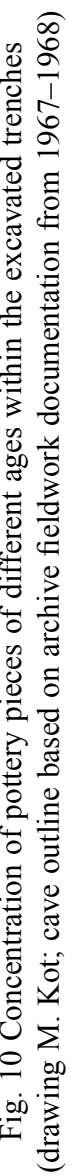
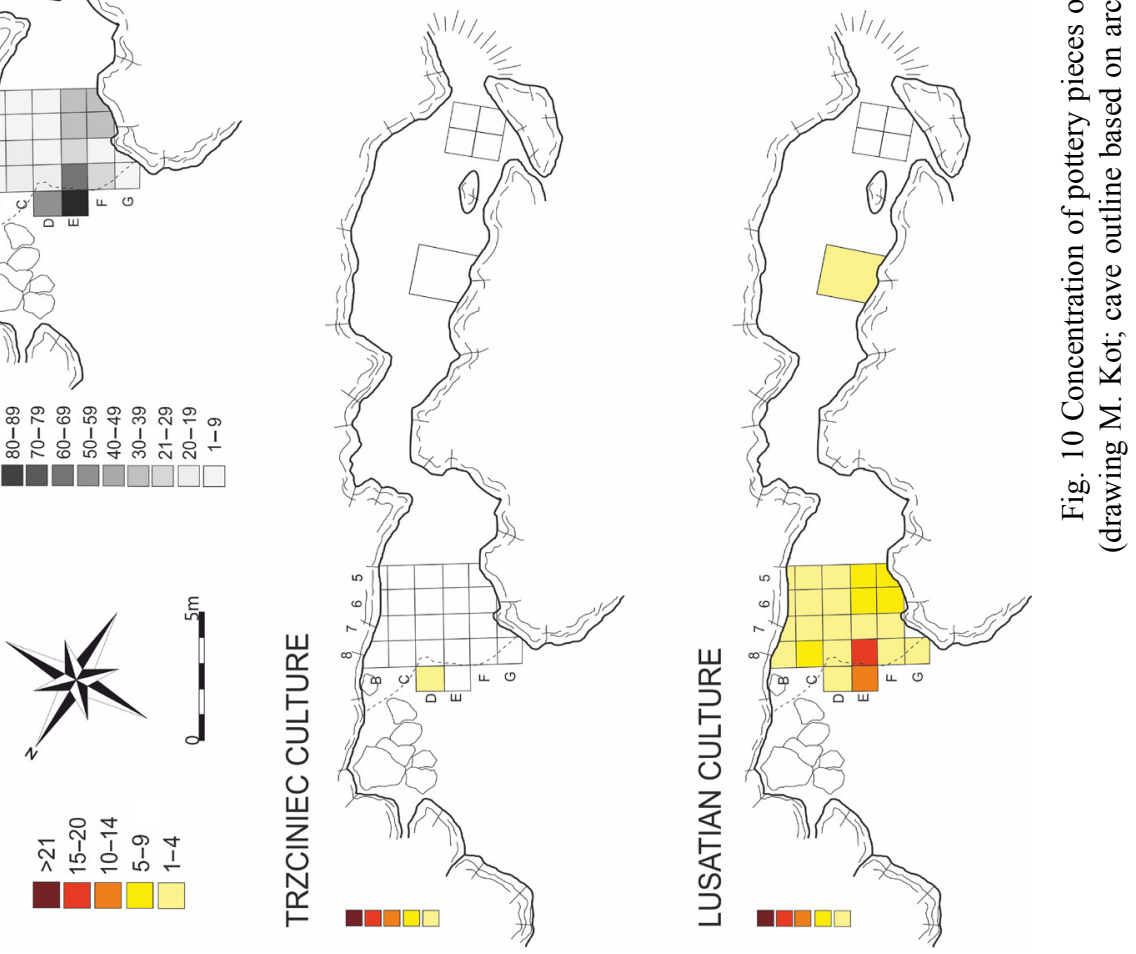


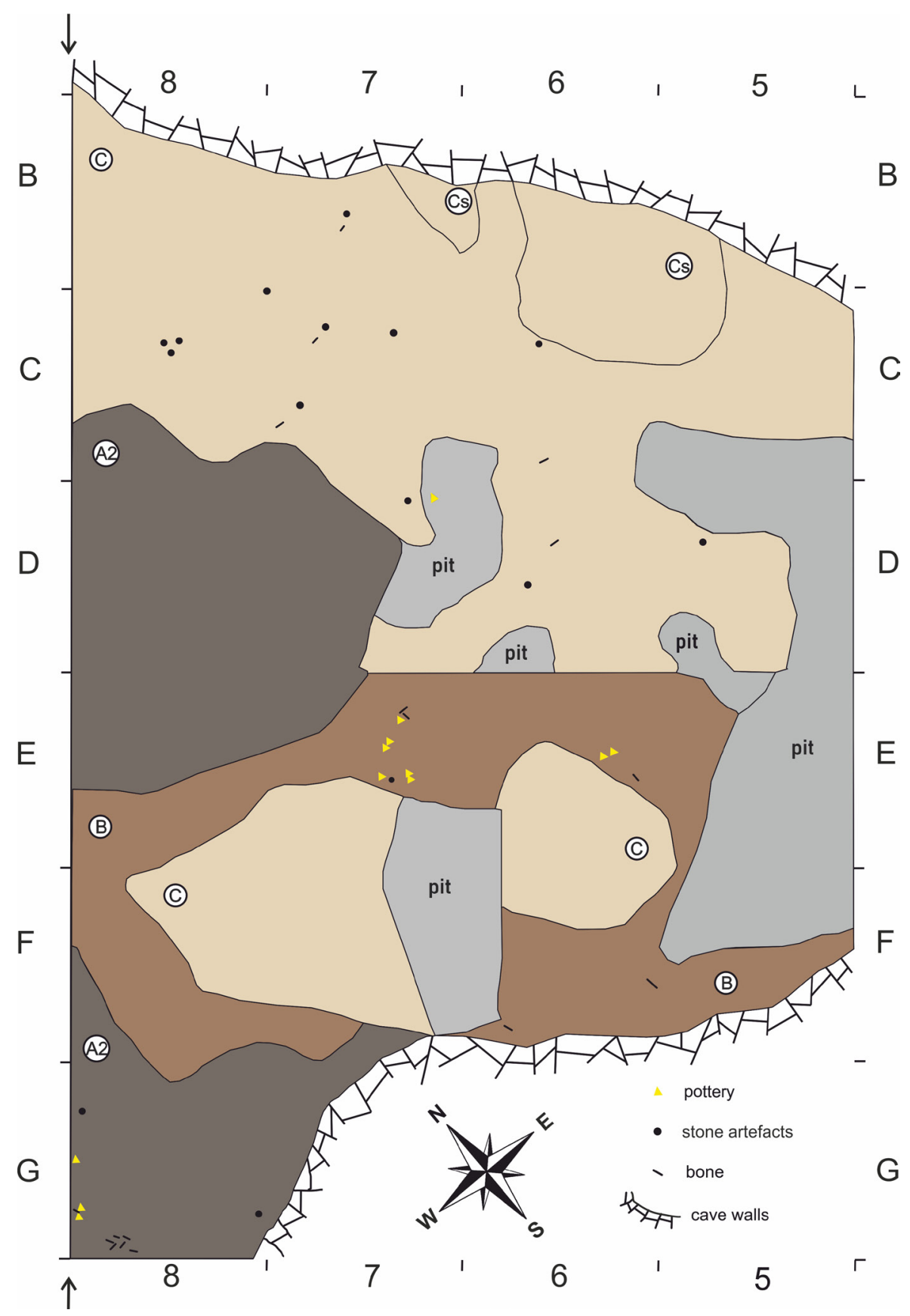

Fig. 11. Plan of trench I (metres B-Dx5-8) and trench III (metres E-G-5-8) at a depth of 90-100 cm beneath the zero level determined by W. Chmielewski (approx. $70 \mathrm{~cm}$ beneath the surface). One can see several pits dug into the loess layer (C) and humus layers (A2, B). Trench I was excavated in 1967 as the first one; trench III was excavated later, so the plans do not fit each other due to level incompatibility (drawing M. Kot; based on the original field documentation from 1967) 


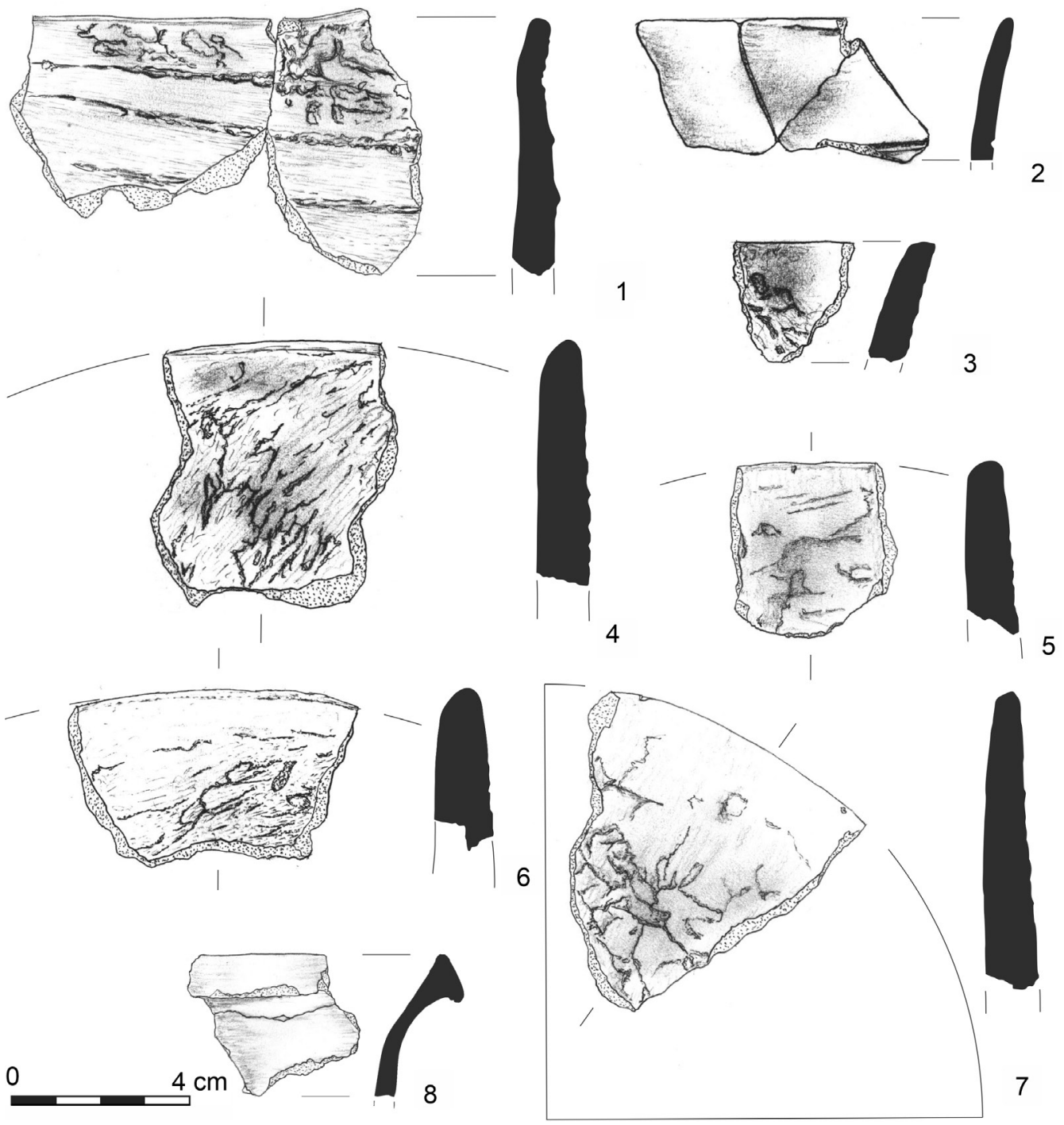

Fig. 12. Pottery linked with the Lusatian culture found in the "above Niedostepna Cave" rockshelter and the "under Tunel Wielki" rockshelter found by W. Chmielewski during archaeological fieldworks conducted in 1967/68 (drawings M. Szeliga)

Tunel Wielki Cave (ChMielewski 1988). These are four rim parts of plates (Fig. 12: 4-7) without any ornamentation on their surfaces. The other artefacts are two rims with roughened surfaces (Fig. 12: 1, 3) and a single smoothed rim originating from a vessel decorated with a single engraved line on the neck (Fig. 12: 2). These materials can be dated analogically to the Tunel Wielki Cave assemblage, allowing us to identify another two cave sites with ephemeral Lusatian occupation.

Apart from the sites like Wierzchowska Górna Cave, Mamutowa Cave, and Ciemna Cave, Tunel Wielki and Rock Shelter above Niedostepna Cave located directly beneath 
it produced the largest pottery assemblage related to the Lusatian culture. Recent studies show that at least some of the caves, e.g. Ciasna Cave, could have been used not only as settlement sites but also for ritual purposes (CZAJKa 2019). The pottery assemblage from Tunel Wielki Cave indicates that the cave was used for settlement, and the same applies to the underlying rock shelters.

Protohistorical material is represented by scanty potsherds dated to the Younger and Late Roman periods and possibly also the Early Migration period, which seems to be a standard situation in many caves of the Cracow Upland.

Of particular importance are the results of examination of medieval pottery, demonstrating at least two episodes of medieval human activity in the cave. While the later group of pottery sources have close affinities with numerous assemblages known from many cave sites of the region (WOJENKA 2018: 223, fig. 14.1), particular attention should be drawn to the earlier set of ceramics, conditionally dated from the $11^{\text {th }}$ to the $12^{\text {th }}$ century. The evidence for such an early date of human activity in caves in the Ojców area is scarce. It is limited to merely a few caves, like Okopy Wielka Dolna (CZARNOwsKi 1898; WoJENKA 2012b), Ciemna, Łokietka, Mamutowa, Wierzchowska Górna (cf. Liwoch 2014: 420-422) and Koziarnia (Кот et al. 2019: 66). The early evidence of medieval activity at the last site is noteworthy, since Koziarnia lies near Tunel Wielki Cave.

All the aforementioned sites likely served as places for hiding and refuge for the local communities (see WoJENKa 2018: 242).

To conclude, it is fair to say that the examination of the archaeological sources from Tunel Wielki has shed much light on human activity in caves during the post-Neolithic period, not only demonstrating the site's scientific potential but also providing a valuable benchmark for further study on the caves of the region.

AcKnowledgements. This work was supported by the National Science Centre in Poland (grant number 2016/22/E/HS3/00486). We are very grateful to the Authorities of Ojców National Park who gave their permission for new archaeological fieldworks in Tunel Wielki Cave. We would like to thank also Prof. Teresa Madeyska and Prof. Stefan K. Kozłowski, who provided valuable information on the old fieldworks. We are also grateful to both reviewers for their valuable remarks, which have enabled us to improve the manuscript.

\section{REFERENCES}

Buкo A., 1990. Ceramika wczesnopolska. Wprowadzenie do badań. Wrocław.

Buko A., 2008. Pottery fragmentation as a source of archaeological information. Archaeologia Polona 46: $149-162$.

ChMielewski W., 1988. Ogólna charakterystyka jaskiń Doliny Sąspowskiej pod względem występowania w nich źródeł archeologicznych. In: Chmielewski W. (Ed.), Jaskinie Doliny Sąspowskiej. Tło przyrodnicze osadnictwa pradziejowego. Prace Instytutu Archeologii UW. Warszawa: 5-17.

Chmielewski W., Kozıowski S. K., 1968. Sąspów, pow. Olkusz. Informator Archeologiczny. Badania 1967 r.: $18-19$.

Chmielewski W., Kowalski K., Madeyska-Niklewska T., Sych L., 1967. Wyniki badań osadów jaskini Koziarni w Sąspowie, pow. Olkusz. 
Chmielewski W., KozŁowski S. K., Niklewska T., 1969. Sąspów, pow. Olkusz. Jaskinia Tunel, Wielki. Schronisko nad J. Niedostępną. Schronisko pod Tunelem Wielkim. Informator Archeologiczny. Badania 1968 r.: $23-24$.

CzAJKA G., 2019. Źródła archeologiczne z holoceńskich nawarstwień sedymentu Jaskini Ciasnej z badań w latach 1969-70 i 2018 (BA thesis). University of Warsaw.

Czarnowski S. J., 1898. Wykopalisko monet w Jaskini „Okopy” Wielkiej nad Prądnikiem Ojcowskim. Wiadomości Numizmatyczno-Archeologiczne III (2-3): 445-453.

DoBRZAŃSKa H., 1990. Osada z późnego okresu rzymskiego w Igołomi, woj. krakowskie. Kraków.

Durczewski Z., 1946. Grupa górnośląsko-małopolska kultury łużyckiej w Polsce, część I. Kraków.

Fogel J., 1979. Studia nad uzbrojeniem ludności kultury łużyckiej w dorzeczy Odry i Wisły: broń zaczepna. Poznań.

GóRSKI J., 2007. Chronologia kultury trzcinieckiej na lessach niecki nidziańskiej. Kraków.

HoŁubowicz W., 1950. Garncarstwo wiejskie zachodnich terenów Białorusi. Toruń.

Jakubczak M., Budziszewski J., Leloch M., Gryczewska N., Kot M., Szeliga M., (in print). Pole górnicze „Dąbrówka-I”. Neolityczna kopalnia krzemienia jurajskiego ze śladowo zachowaną rzeźbą nakopalnianą.

Jarosz P., Wlodarczak E., Wlodarczak P., 2012. Ratownicze badania autostradowe w dolinie Wisły: Kraków-Bieżanów, stanowisko 33. In: Kadrow S. (Ed.) RAPORT 2007-2008, t. I. Warszawa: 555-576.

J̨̨DRYsIK J., 2016. Osadnictwo na Wyżynie Olkuskiej w epoce brązu i we wczesnej epoce żelaza (MA thesis). Jagiellonian University.

Kaczanowski P., 1987. Drochlin. Ciałopalne cmentarzysko kultury przeworskiej z okresu wpływów rzymskich. Kraków.

Kот M., Szeliga M., Wojenka M., 2019. Badania wykopaliskowe Stefana Krukowskiego w Dolinie Sąspowskiej. Wiadomości Archeologiczne LXX: 65-92.

Krajcarz, M.T., Cyrek, K., Krajcarz, M., Mroczek, P., Sudol, M., Szymanek, M., Tomek, T., MADEYSKA, T., 2016. Loess in a cave - Lithostratigraphic and correlative value of loess and loess-like layers in caves from the Kraków-Częstochowa Upland (Poland). Quaternary International, 399: 13-30.

KubiCA-KABACiŃSKa E., 2001. Podkrakowska ceramika „biała” - analizy surowca, chronologia, kontekst osadniczy. Materiały i Sprawozdania Rzeszowskiego Ośrodka Archeologicznego, XXII: 135-163.

KuKLiŃski A., 2017. Wczesnośredniowieczna stratygrafia kulturowa w południowo-zachodniej części Wzgórza Wawelskiego. Acta Archaeologica Waweliana V. Kraków.

LASAK I., 2014. Materiał ruchomy z osady kultury łużyckiej. In: Masojć M. (Ed.) Obozowiska, osady, wsie. Wrocław-Widawa 17. Wrocław: 89-158.

LECH J., 1971. Z badań nad kopalnią krzemienia na stanowisku I w Sąspowie pow. Olkusz. In: Kozłowski J. K. (Ed.), Z badań nad krzemieniarstwem neolitycznym i eneolitycznym. Kraków: 115-133.

LeCH J., 1980a. PL-14 Jerzmanowice- Dąbrówka I, Wojw. Kraków. In: Weisgerber G., Slotta R., Weiner, J. (Eds), 5000 Jahre Feuersteinbergbau. Die Suche nach dem Stahl der Steinzeit. Deutschen BergbauMuseum Bochum, Veröffentlichungen aus dem Deutschen Bergbau-Museum Bochum 22: 612-615. Bochum.

LeCH J., 1980b. PL-15 Sąspów I, Jerzmanowice, Wojw. Kraków. In: Weisgerber G., Slotta R., Weiner J. (Eds), 5000 Jahre Feuersteinbergbau. Die Suche nach dem Stahl der Steinzeit. Deutschen BergbauMuseum Bochum, Veröffentlichungen aus dem Deutschen Bergbau-Museum Bochum 22: 616-619.

LECH J., 1981. Górnictwo krzemienia społeczności wczesno rolniczych na Wyżynie Krakowskiej koniec VI tysiąclecia - 1 połowa IV tysiąclecia p.n.e. Wrocław-Warszawa-Kraków-Gdańsk-Łódź. 
LeCH J., 2001. Archeologia Jury Ojcowskiej w zarysie. In: Lech J., Partyka J. (Eds), Z archeologii Ukrainy i Jury Ojcowskiej. Ojców: 127-182.

LeńczyK G., 1938. Grodzisko w Piekarach. Prace Prehistoryczne 2. Kraków.

LePówna B., 1968. Garncarstwo gdańskie w X-XIII wieku. Gdańsk.

Liana T., 1970. Chronologia względna kultury przeworskiej we wczesnym okresie rzymskim. Wiadomości Archeologiczne XXV/4: 429-491.

Liwoch R., 2014. Importy staroruskie w Polsce. Przykłady ze zbiorów dawnych Muzeum Archeologicznego w Krakowie. In: Toločko P. (Ed.), Mìsta davn'oï Rusì. Kiïv: 415-423.

Mackiewicz M., 2012. Nowożytna ceramika artystyczna z badań archeologicznych przy kościele św. Piotra i Pawła na Ostrowie Tumskim we Wrocławiu. In: Pankiewicz A. (Ed.), Nowożytny cmentarz przy kościele św. Piotra i Pawła na Ostrowie Tumskim we Wrocławiu (lata 1621-1670). Wratislavia Antiqua 17: 129-160.

MadeYsKa T., 1988. Osady jaskiń i schronisk Doliny Sąspowskiej. In: Chmielewski W. (Ed.), Jaskinie Doliny Sąspowskiej. Tło przyrodnicze osadnictwa pradziejowego. Prace Instytutu Archeologii UW. Warszawa: $77-173$.

MarCiniaK J., 1960. Cmentarzysko szkieletowe z okresu wczesnośredniowiecznego w Strzemieszycach Wielkich pow. Będzin. Materiały Wczesnośredniowieczne V: 141-186.

MościBrodzKa J., 1971. Zasiedlenie jaskiń Wąwozu Koziarni w Sąspowie, w górnym plejstocenie. (MA thesis). University of Warsaw.

Nadachowski A., 1988. Fauna kopalna płazów, gadów i ssaków w osadów jaskiń i schronisk Doliny Sąspowskiej. In: Chmielewski W. (Ed.), Jaskinie Doliny Sąspowskiej. Tło przyrodnicze osadnictwa pradziejowego. Prace Instytutu Archeologii UW. Warszawa: 19-38.

Niegoda J., 1999. Naczynia ceramiczne. In: Buśko C., Piekalski J., (Eds), Ze studiów nad życiem codziennym w średniowiecznym mieście. Wratislavia Antiqua I: 157-182.

Nierychlewska A., 2011. Ceramika naczyniowa z osady w Przeczycach. In: Badura R., Abłamowicz D. (Eds), Wczesnośredniowieczna osada produkcyjna w Przeczycach, województwo śląskie. Rocznik Muzeum Górnośląskiego w Bytomiu. Archeologia 19: 56-88, 133-150.

NowaK M., Liwoch R., Moskal-del Hoyo M., Rauba-Bukowska A., Wilczyński J., 2016. Korzkiew 5 najstarsze stanowisko średniowieczne na Wyżynie Olkuskiej. Materiały Archeologiczne XLI: 245-262.

RADWAŃSKI K., 1968. Wczesnośredniowieczna ceramika krakowska i zagadnienie jej chronologii. Materiały Archeologiczne IX: 5-71.

RoDZIŃSKA-NowAK J., 2006. Jakuszowice stanowisko 2. Ceramika z osady kultury przeworskiej z młodszego i późnego okresu wpływów rzymskich i wczesnej fazy okresu wędrówek ludów. Kraków.

RoDZIŃSKA-NowAK J., 2010. Uwagi o chronologii ceramiki wykonanej na kole garncarskim w kulturze przeworskiej w świetle wyników analizy materiałów zabytkowych z osady w Jakuszowicach, woj. świętokrzyskie, i cmentarzyska w Opatowie, woj. śląskie. In: Machajewski H., Jurkiewicz B. (Eds), Ceramika rzemieślnicza jako źródło do badań nad zróżnicowaniem garncarstwa kultury przeworskiej. Pułtusk: 71-87.

Rook E., 1980. Osadnictwo neolityczne w jaskiniach Wyżyny Krakowsko-Częstochowskiej. Materiały Archeologiczne XX: 5-130.

Rozmus D., 2014. Wczesnośredniowieczne zagłębie hutnictwa srebra i ołowiu na obszarach pogranicza Górnego Śląska i Małopolski (druga połowa XI-XII/XIII wiek). Kraków.

SudER W., 2000. Osada kultury łużyckiej na stanowisku Iwanowice-Babia Góra II. Sprawozdania archeologiczne 52: 171-219. 
URBANIAK A., 2008. Osada kultury przeworskiej i kultury wczesnosłowiańskiej na stanowisku 3 w Złotej, pow. Sandomierz. Łódź.

WoJenka M., 2012a. Jaskinie Wyżyny Krakowsko-Częstochowskiej w średniowieczu. Wstęp do problematyki. Prądnik. Prace i Materiały Muzeum im. prof. Władysława Szafera 22: 7-43.

WoJenka M., 2012b. Zapomniane naczynie. Kilka uwag o pojemniku na skarb srebrny z jaskini Okopy Wielkiej, Dolnej w Ojcowie. Notae Numismaticae VII: 227-241.

WoJenka M., 2016. Sprawozdanie z badań wykopaliskowych przeprowadzonych na zamku w Ojcowie w latach 2006-2014. Prądnik. Prace i Materiały Muzeum im. Prof. Władysława Szafera 26: 199-224.

WoJenka M., 2018. Knights in the dark: on the function of Polish caves in the Middle Ages. In: Bergsvik K. A., Dowd M. (Eds), Caves and ritual in medieval Europe AD 500-1500. Oxford-Philadelphia: 232-246.

WoJenka M., WilcZyŃski J., ZastaWny A., 2016. Archaeological excavations in Żarska Cave in Żary Kraków district, 2012-2015: an interim report. Recherches Archéologiques NS 8: 185-204.

Wojenka M., Krajcarz M. T., Szczepanek A., Wilczyński J., 2017. Sprawozdanie z badań wykopaliskowych przeprowadzonych w Jaskini Tunel Wielki w Wąwozie Koziarnia w 2016 roku. Prądnik: prace i materiały muzeum im prof. Władysława Szafera 27: 147-168.

Wojenka M., BojęŚ-BiaŁasik A., Szyma M., 2019. Trzynastowieczna zabudowa murowana w Grodzisku koło Skały w świetle wyników najnowszych badań archeologiczno-architektonicznych. In: Wojenka M., Langner S. (Eds), Konwent Klarysek skalskich a dziedzictwo kulturowe i religijne bł. Salomei. Kielce: $69-110$.

Wojenka M., Jaskulska E., Popovic D., Baca M., Frog, Fetner R., Wertz K., Rataj K., Gryczewska N., Kosiński T., Kот M., (in press) The girl with finches: a unique post-medieval burial in Tunel Wielki Cave, southern Poland, Prähistorische Zeitschrift.

ZASTAWNy A., 2006. Osadnictwo społeczności badeńskiego kręgu kulturowego w Jurze Ojcowskiej na TLE regionów sąsiednich. In: Lech J., Partyka J. (Eds), Jura Ojcowska w pradziejach i w początkach państwa polskiego. Ojców: 439-458.

Zastawny A., 2015. The Baden complex in Lesser Poland - horizons of cultural influences. In: Nowak M., Zastawny A. (Eds), The Baden culture around the Western Carpathians. Via Archaeologica. Cracow: 119-150. 
